\title{
PENGEMBANGAN APLIKASI STANDAR PRODUKSI DAN PENGGUNAAN BAHAN PADA PERUSAHAAN KULIT IMITASI BERBASIS WEBSITE
}

\author{
Muchamad Rusdan', Imam Yunianto ${ }^{2}$, Kurniawan ${ }^{3}$ \\ Informatika ${ }^{1,2,3}$ \\ Sekolah Tinggi Teknologi Bandung ${ }^{1,2,3}$ \\ Jl. Soekarno-Hatta No. 378, Kota Bandung ${ }^{1,2,3}$ \\ rusdan@ sttbandung.ac.id ${ }^{1}$
}

\begin{abstract}
Abstrak
Tujuan dari penelitian ini, yaitu memberikan kemudahan dalam membaca artikel standar produksi dan penggunaan bahan kulit imitasi. Membantu mengurangi tingkat kesalahan dalam melihat artikel standar produksi dan penggunaan bahan oleh operator. Operator dapat lebih mudah dalam memasukan dan merubah data standar produksi dan penggunaan bahan kulit imitasi. Membantu operator yang sudah lanjut usia dan memiliki masalah pada penglihatan dalam melihat dan menentukan standar produksi dan penggunaan bahan. Membantu mengurangi kesalahan operator shift malam yang kurang konsentrasi saat melihat buku standar produksi dan penggunaan bahan kulit imitasi dikarenakan mengantuk. Penelitian ini menggunakan pendekatan kualitatif dengan teknik pengumpulan data menggunakan teknik observasi, wawancara, dan studi pustaka. Model pengembangan sistem yang digunakan dalam penelitian ini adalah model Waterfall. Hasil penelitian ini menunjukkan bahwa aplikasi standar produksi dan penggunaan bahan kulit imitasi sangat mudah untuk digunakan, cukup cepat dalam memproses atau menjalankan fungsinya, sangat membantu operator yang mempunyai masalah pada pengelihatannya, sudah cukup layak untuk menggantikan standar produksi yang sebelumnya.
\end{abstract}

Kata kunci :

Kulit Imitasi, Standar Produksi, Penggunaan Bahan, Model Waterfall, Website.

\begin{abstract}
The purpose of this research is to provide ease in reading articles on the standard production and use of imitation leather. Help reduce error rates when viewing standard articles on production and material usage by operators. Operators can more easily enter and change production and usage data standards for imitation leather. It is helping operators who are elderly and have vision problems in seeing and determining production standards and material usage. Help reduce night shift operator errors that lack concentration when looking at the standard production book and the use of faux leather due to drowsiness. This study uses a qualitative approach to data collection techniques using observation, interviews, and literature study. The system development model used in this study is the Waterfall model. The results of this study indicate that the application of standard production and the use of imitation leather is very easy to use, is quite fast in processing or carrying out its functions, is very helpful for operators who have problems with their eyesight. It is quite feasible to replace previous production standards.
\end{abstract}

Keywords :

Imitation Leather, Production Standards, Material Use, Waterfall Models, Website. 


\section{Pendahuluan}

Standar produksi adalah pedoman yang dapat digunakan untuk melakukan proses produksi. Standar produksi menyediakan data sebagai dasar untuk pengambilan keputusan dalam proses produksi (Herawati \& Mulyani, 2016). Dalam suatu perusahaan, standar produksi adalah salah satu faktor terpenting dalam mendukung kesuksesan perusahaan. Dengan standar produksi, implementasi proses produksi akan berjalan dengan baik, dan proses produksi dapat berjalan seperti yang diharapkan oleh perusahaan dan konsumen. Standar produksi juga digunakan oleh perusahaan untuk menjaga kualitas hasil produksi (Nagy et al., 2018).

Pada sebuah perusahaan yang bergerak di bidang kulit imitasi. Perusahaan selalu mengembangkan semua proses yang ada mulai dari pembelian, bahan baku, hingga penjualan produk yang siap dijual. Oleh karena itu, proses produksi harus dipertahankan untuk menjaga kualitas hasil produksi. Namun, di perusahaan kulit imitasi standar, produksi dan penggunaan bahan kulit imitasi masih menggunakan proses manual dan hanya menggunakan lembaran kertas yang dicatat, karena jumlah artikel kulit imitasi yang diproduksi sangat besar, sekitar tujuh ratus artikel kulit imitasi dan masih menggunakan tulisan yang sangat kecil sehingga rentan terhadap kesalahan, terutama untuk pekerja lanjut usia yang penglihatannya terganggu. Pada lansia, pekerja, tentu saja, membutuhkan waktu yang lama dalam menentukan standar produksi dan penggunaan kulit imitasi. Selain itu, karena sistem kerja shift yang memungkinkan shift malam, tentu saja, ada banyak kesalahan dalam membaca standar produksi dan penggunaan material, karena operator kerja shift malam terlihat mengantuk dan tidak fokus pada melihat produksi standar dan penggunaan material. buku.

Karyawan membutuhkan keakuratan yang sangat baik dalam membaca artikel dalam buku standar produksi dan penggunaan bahan, selain itu jika ada perubahan data dalam artikel itu akan sulit untuk diubah, jika perubahan data yang salah akan berdampak pada proses produksi yang sedang berjalan atau sedang berlangsung, operator akan mengalami kebingungan dalam menjalankan proses produksi dan dapat mengganggu jalannya proses produksi dan kesalahan ini dapat menyebabkan perusahaan menderita kerugian.
Berdasarkan hal ini, dipandang perlu untuk merancang aplikasi untuk informasi tentang standar produksi dan penggunaan bahan kulit imitasi yang dapat memudahkan operator dalam membaca setiap artikel dari produksi standar dan penggunaan kulit imitasi. Oleh karena itu, tujuan dari penelitian ini adalah untuk memberikan kemudahan dalam membaca artikel tentang standar produksi dan penggunaan kulit imitasi. Bantu mengurangi tingkat kesalahan dalam melihat produksi artikel standar dan penggunaan bahan oleh operator. Operator dapat lebih mudah memasukkan dan mengubah data pada produksi standar dan penggunaan kulit imitasi. Ini membantu operator yang berusia lanjut dan memiliki masalah penglihatan dalam melihat dan menentukan standar produksi dan penggunaan material. Bantu mengurangi kesalahan operator shift malam yang kurang konsentrasi ketika melihat buku produksi standar dan penggunaan kulit imitasi karena kantuk.

\section{KAJIAN LITERATUR}

\section{II.1 Konsep Dasar Aplikasi Standar Produksi Kulit Imitasi}

Aplikasi adalah sekumpulan atribut yang terdiri dari instruksi, prosedur, formulir, dan laporan yang dirancang sehingga pengguna dapat mengakses data (Neyfa \& Tamara, 2016). Aplikasi juga dapat diartikan sebagai perangkat lunak yang berisi instruksi yang dapat digunakan untuk mengolah data menjadi informasi (Neyfa \& Tamara, 2016). Menurut Jogiyanto (1999), Aplikasi merupakan proses cara manual yang ditransformasikan menjadi komputer dengan membuat suatu sistem atau program sehingga data yang diolah menjadi lebih efisien (Marhalim et al., 2018). Kemudian menurut Dhanta (2009) menyatakan, aplikasi adalah perangkat lunak yang dibuat untuk menyelesaikan masalah dan tugas tertentu.

Menurut Widiastuti (2006) menyatakan, produksi adalah kegiatan yang mengubah input menjadi output. Aktivitas-aktivitas ini dalam ekonomi biasa diekspresikan dalam fungsi produksi. (Widiastuti, 2006). Selanjutnya Gaspesz (2004) mengatakan, produksi adalah fungsi dasar dalam setiap organisasi yang mencakup kegiatan yang bertanggung jawab untuk menciptakan produk bernilai tambah yang merupakan output dari masing-masing organisasi industri tersebut (Zulkifli et al., 2017). Menurut Sofjan Assauri (2008) menjelaskan, produksi adalah kegiatan yang mengubah input, termasuk semua

Muchamad Rusdan, Imam Yunianto, Kurniawan 
kegiatan atau kegiatan yang menghasilkan barang atau jasa, serta kegiatan lain yang mendukung bisnis menghasilkan produk dalam bentuk barang atau jasa (Budiartami \& Wijaya, 2019).

Kulit imitasi adalah kulit sintetis yang tidak menggunakan kulit binatang. Kulit imitasi telah dibuat menjadi berbagai jenis dan sangat mirip dengan kulit asli (Limantara et al., 2017). Mulai dari glossy, motif, warna, dan bahkan bisa jauh lebih baik untuk mengembangkan motif sesuai selera. Kulit imitasi adalah lembaran kulit buatan yang terbuat dari senyawa Poly Chloride (PVC) atau Polyurethane (PU) sebagai lapisan atas dan kain sebagai lapisan dasar yang berfungsi sebagai penguat, dan ada pula yang berbusa di lapisan tengah atau tanpa busa, kalender, coating atau laminating (Limantara et al., 2017). Calendaring adalah proses penggilingan senyawa PVC atau PU lunak menggunakan mesin penekan untuk membentuk lembaran plastik, coating adalah pelapisan bahan plastik lunak pada kain penguat, dan laminating adalah penggabungan dua atau lebih lapisan plastik dengan kain penguat menggunakan lem atau panas. Menurut struktur lapisan kain penguat, kulit imitasi dapat diklasifikasikan menjadi tiga jenis, yaitu struktur satu lapisan, lapisan kain penguat dengan satu lapisan bahan polimer. Struktur dua lapisan, yaitu lapisan kain penguat dengan dua lapisan yang terdiri dari lapisan atas dan lapisan dasar yang terbuat dari bahan polimer. Struktur tiga lapis adalah lapisan kain penguat dengan tiga lapisan yang terdiri dari lapisan atas, lapisan tengah, dan lapisan dasar yang terbuat dari bahan polimer.

\section{II.2 Konsep Website}

Situs web adalah sejumlah halaman web yang memiliki topik terkait, terkadang disertai dengan file seperti gambar, video atau jenis file lainnya. (Supriyanta \& Nisa, 2015). Situs web biasanya ditempatkan setidaknya pada server web yang dapat diakses melalui jaringan seperti internet, atau Local Area Network (LAN) melalui alamat internet yang dikenal sebagai Uniform Resource Locator (URL). Halaman web adalah file yang ditulis sebagai file teks biasa yang disusun dan digabungkan sedemikian rupa dengan instruksi berdasarkan HTML atau XHTML, yang sering juga disisipkan dengan bahasa skrip lain seperti PHP. File tersebut kemudian diterjemahkan oleh web browser dan ditampilkan seperti halaman pada monitor komputer. Halaman web ini diakses oleh pengguna melalui protokol komunikasi jaringan yang disebut Hypertext Transfer Protocol (HTTP). Kombinasi semua situs yang dapat diakses secara publik di internet juga disebut World Wide Web (WWW) (Supriyanta \& Nisa, 2015).

\section{II.3 Metode Penelitian}

Penelitian ini menggunakan pendekatan kualitatif dengan teknik pengumpulan data menggunakan observasi, wawancara, dan studi literatur. Pengamatan dan wawancara dilakukan dengan perusahaan kulit imitasi yang masih menggunakan dokumentasi standar produksi dan penggunaan bahan kulit imitasi secara manual dalam bentuk buku atau belum terkomputerisasi. Sedangkan penelitian kepustakaan diperoleh dari buku, jurnal, tesis, tesis, dan internet. Model pengembangan sistem yang digunakan dalam penelitian ini adalah model Waterfall, siklusnya dapat dilihat pada Gambar 1.

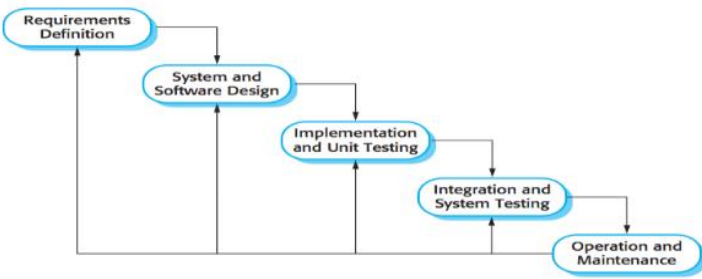

Gambar 1. Siklus Metode Waterfall

\section{ANALISIS DAN PERANCANGaN}

\section{III.1 Analisis Sistem}

Sebelum memasuki tahap desain program, tahap analisis dilakukan sehingga nantinya dalam mendesain aplikasi tidak ada kesalahan. Analisis adalah tahap penting sebelum memasuki tahap berikutnya, tujuan analisis ini secara luas untuk menghasilkan bentuk desain yang dapat memenuhi kebutuhan dan menemukan solusi yang tepat untuk masalah tersebut.

Analisis persyaratan aplikasi untuk standar produksi kulit imitasi berbasis web, yaitu perangkat keras komputer yang digunakan dalam pengembangan sistem. Perangkat lunak yang digunakan dalam pengembangan sistem seperti sistem operasi Windows, Click Chart, Balsamiq, dan Sublime, serta data yang dibutuhkan dalam pembuatan aplikasi adalah data yang digunakan dalam data produksi standar dan penggunaan kulit imitasi.

Selain itu, persyaratan dasar yang dibutuhkan oleh pengguna dalam penerapan standar produksi dan penggunaan kulit imitasi, yaitu, aplikasi dapat 
membantu pengguna dalam menemukan data produksi standar dan penggunaan bahan lebih cepat. Aplikasi ini membantu pengguna mengurangi tingkat kesalahan dalam menentukan standar produksi dan penggunaan kulit imitasi. Aplikasi ini dapat menampilkan informasi lengkap tentang standar produksi dan penggunaan kulit imitasi dengan cepat menggunakan komputer.

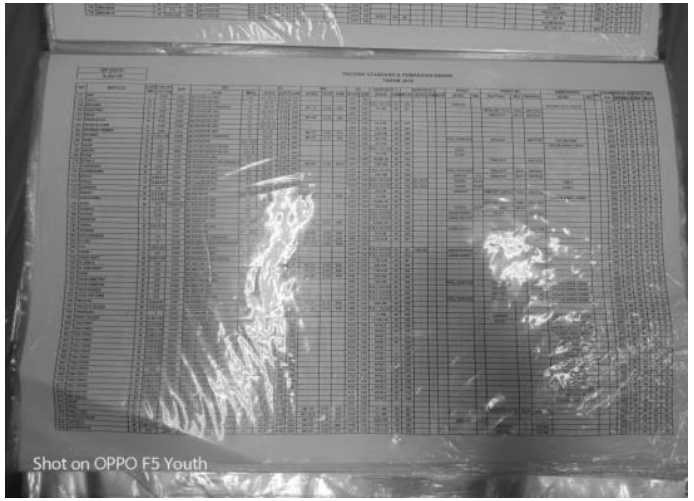

Gambar 2. Buku Standar Produksi dan Penggunaan Bahan

Hasil analisis sistem yang saat ini berjalan pada perusahaan kulit imitasi pada standar produksi dan data penggunaan bahan, mekanisme yang digunakan masih sangat sederhana dan manual atau belum menggunakan komputer. Data yang digunakan masih dalam bentuk beberapa lembar kertas, yang direkam menggunakan tulisan yang sangat kecil. Setiap kali artikel baru dibuat, akan ada pembaruan, jika operator ingin melihat standar produksi yang digunakan membutuhkan akurasi yang baik dan kesulitan menemukan data yang diinginkan. Selain itu, artikel menjadi lebih banyak dari hari ke hari, membuat tulisan yang digunakan lebih kecil, sehingga mempersulit pekerja yang lebih tua untuk melihat standar produksi yang digunakan. Oleh karena itu, perlu untuk membuat aplikasi standar produksi penggunaan kulit imitasi dan bahan untuk membantu operator dalam menentukan standar produksi dan penggunaan bahan kulit imitasi yang akan digunakan dalam proses produksi.

\section{III.2 Perancangan Sistem}

Dalam proses perancangan sistem akan dijelaskan tentang proses-proses yang dimodelkan dalam bentuk Flowchart, Data Flow Diagram (DFD), dan Entity Relational Diagram. Dalam fungsi sistem, beberapa fungsi digunakan, yaitu Operator, karena pengguna ditugasi untuk menemukan produksi standar dan data penggunaan material. Kemudian admin bertugas mengelola data pengguna dan mengelola data pada standar produksi dan penggunaan material.

\section{Flowchart}

Flowchart yang dapat digambarkan untuk aplikasi standar produksi dan penggunaan bahan kulit imitasi sebagai berikut.

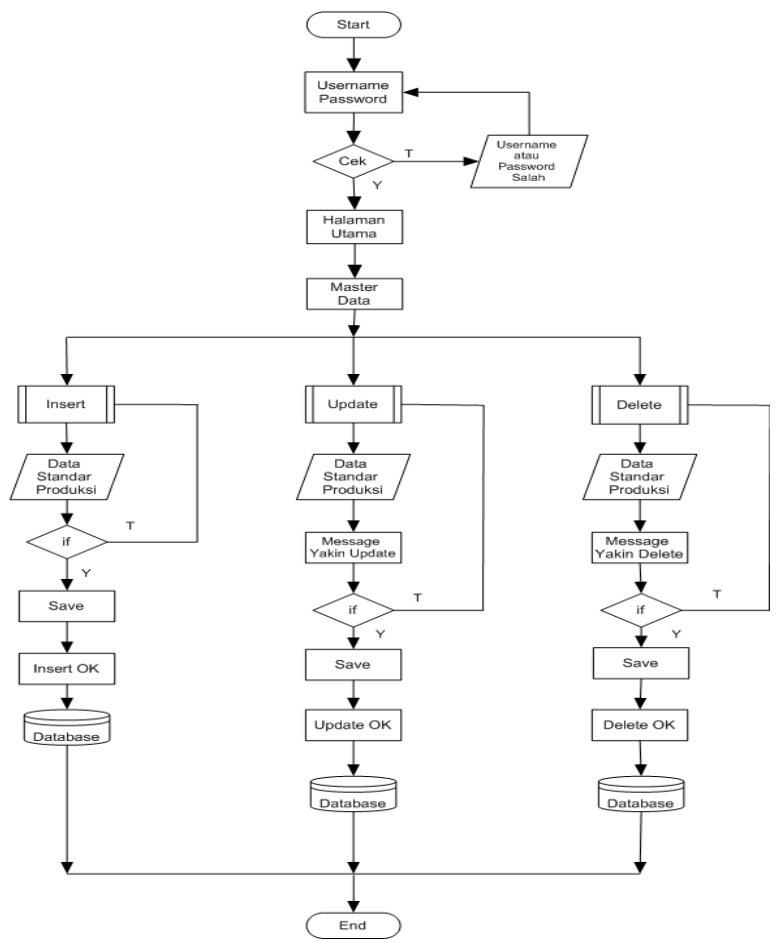

Gambar 3. Flowchart Diagram

\section{Data Flow Diagram (DFD)}

Data Flow Diagram (DFD) yang dapat digambarkan untuk aplikasi standar produksi dan penggunaan bahan kulit imitasi dapat dilihat pada Gambar 4 berikut. 


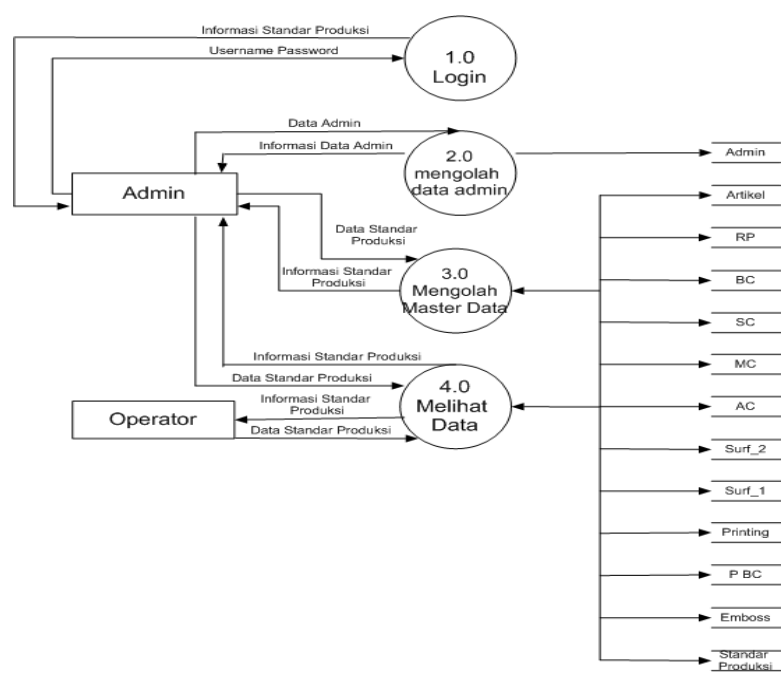

Gambar 4. Data Flow Diagram (DFD)

3. Entity Relational Diagram (ERD)

Entity Relational Diagram (ERD) yang dapat digambarkan untuk aplikasi standar produksi dan penggunaan bahan kulit imitasi dapat dilihat pada Gambar 5 berikut.

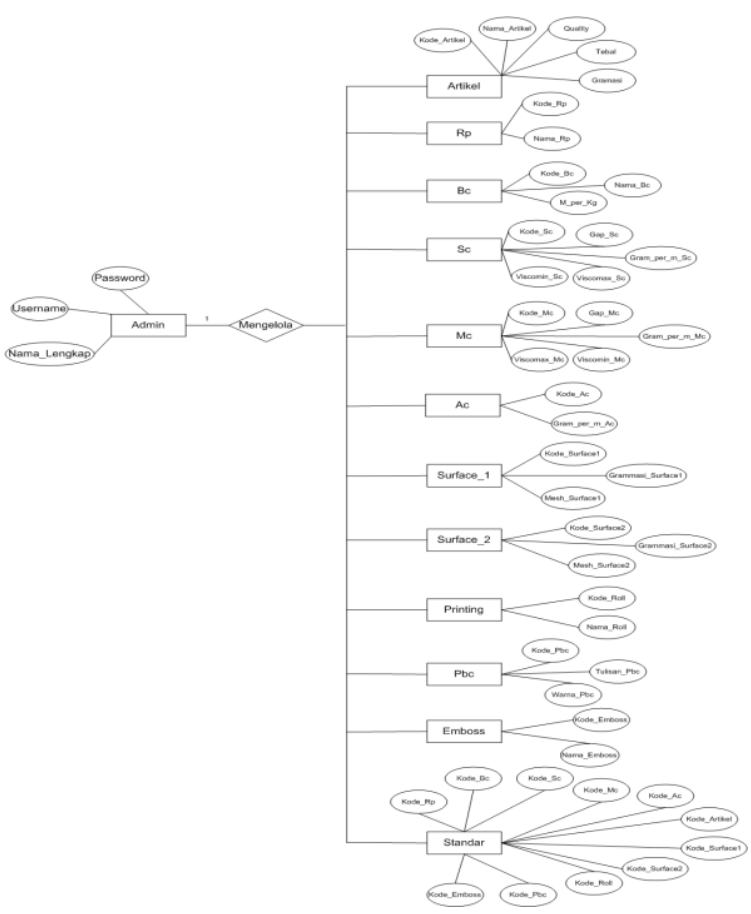

Gambar 5. Desain Entity Relational Diagram (ERD)

4. Desain Login
Login merupakan sebuah standar keamanan yang diterapkan pada aplikasi standar produksi dan penggunaan bahan kulit imitasi, pengguna harus mengisikan username dan password yang telah terdaftar, maka dapat diizinkan untuk mengakses aplikasi standar produksi dan penggunaan bahan kulit imitasi. Adapun desain tampilan login dapat dilihat pada Gambar 6.

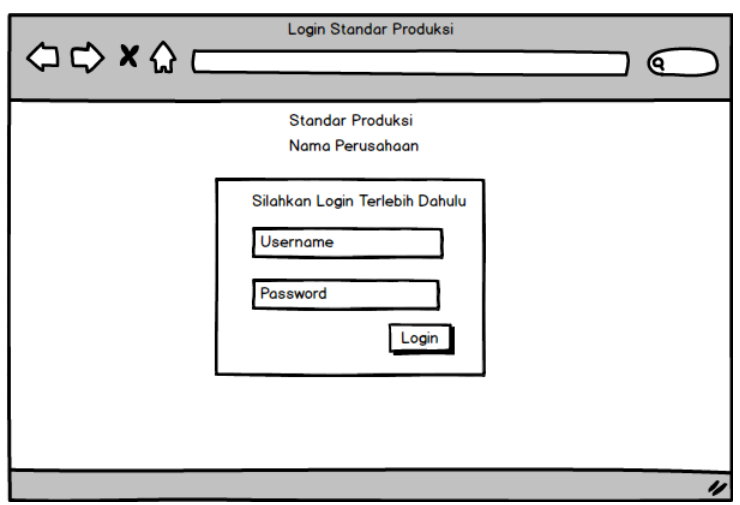

Gambar 6. Desain Tampilan Login

5. Menu Standar Produksi

Menu standar produksi merupakan inti dari data yang akan digunakan, maka dari itu pada standar produksi terdapat beberapa data yang terdapat pada table.

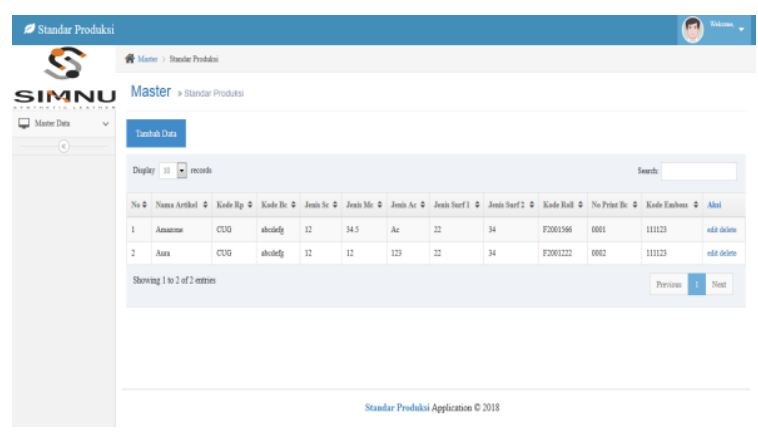

Gambar 7. Master Data Standar Produksi

Berdasarkan Gambar 7 diatas dapat dijelaskan sebagai berikut:

a. No merupakan nomor urut dari data yang ditampilkan.

b. Nama Artikel merupakan penamaan dari jenis kulit imitasi yang diproduksi.

c. Kode Rp merupakan kode yang menunjukkan bentuk release paper atau kertas yang digunakan sebagai bahan dasar pembuatan kulit imitasi.

Muchamad Rusdan, Imam Yunianto, Kurniawan 
d. Kode Bc merupakan kode dari backing cloth atau kain yang digunakan pada lapisan bawah kulit imitasi.

e. Jenis Sc merupakan bagian atas dari kulit imitasi yang digunakan.

f. Jenis Mc merupakan jenis middle coating yaitu lapisan kedua dari lapisan kulit imitasi yang digunakan.

g. Jenis Ac merupakan jenis Adhesive coating perekat antara kulit imitasi dan lapisan kain yang digunakan.

h. Jenis Surf 1 merupakan jenis pelapis yang digunakan untuk mempertahankan warna pada kulit imitasi pertama sesuai dengan kebutuhan.

i. Jenis Surf 2 merupakan jenis pelapis yang digunakan untuk mempertahankan warna pada kulit imitasi kedua sesuai dengan kebutuhan.

j. $\quad$ Kode Roll merupakan kode yang digunakan pada roll motif printing yang digunakan untuk memberikan motif tertentu pada kulit imitasi.

k. No print $\mathrm{BC}$ merupakan tulisan yang digunakan pada bagian kain kulit imitasi.

1. Kode Emboss merupakan kode roll yang digunakan untuk memberikan motif tertentu pada kulit imitasi dengan cara memanaskan terlebih dahulu kulit imitasi kemudian di press sehingga didapatkan bentuk atau motif yang diinginkan.

\section{III.3 Pengujian Sistem}

Berdasarkan rencana pengujian yang telah disusun, maka dapat dilakukan pengujian dengan hasil sebagai berikut:

1. Pengujian Login

Table 1. Hasil Uji Login Dengan Akun Benar

\begin{tabular}{ll}
\hline \hline Data Masukan & $\begin{array}{l}\text { Username : Admin } \\
\text { Password : Admin }\end{array}$ \\
\hline \hline Yang Diharapkan & $\begin{array}{l}\text { Data login dimasukkan lalu mengklik } \\
\text { tombol login maka dilakukan proses } \\
\text { pengecekan data login. Apabila data }\end{array}$ \\
& $\begin{array}{l}\text { login benar maka admin mendapatkan } \\
\text { haknya sebagai pengolah data dengan } \\
\text { akses penuh. }\end{array}$ \\
\hline \hline Pengamatan & $\begin{array}{l}\text { Dapat mengisi data login sebagai } \\
\text { admin dan tombol login dapat } \\
\text { berfungsi sesuai dengan yang } \\
\text { diharapkan }\end{array}$ \\
\hline \hline Kesimpulan & Diterima \\
\hline \hline
\end{tabular}

Table 2. Hasil Uji Login Dengan Akun Salah

\begin{tabular}{|c|c|}
\hline Data Masukan & $\begin{array}{l}\text { Username : kosong } \\
\text { Password: kosong }\end{array}$ \\
\hline Yang Diharapkan & $\begin{array}{l}\text { Dapat Menampilkan } \\
\text { "Username belum } \\
\text { "Password belum diisi" }\end{array}$ \\
\hline Pengamatan & $\begin{array}{l}\text { Pesan kesalahan "Username belum } \\
\text { diisi" dan "Password belum diisi" } \\
\text { ditampilkan maka user dan admin } \\
\text { tidak dapat melakukan login sesuai } \\
\text { dengan yang diharapkan }\end{array}$ \\
\hline Kesimpulan & Ditolak \\
\hline Data Masukan & $\begin{array}{l}\text { Username : aa (sembarang) } \\
\text { Password: aa (sembarang) }\end{array}$ \\
\hline Yang Diharapkan & $\begin{array}{l}\text { Dapat Menampilkan kesalahan } \\
\text { Username dan Password yang } \\
\text { dimasukkan salah. }\end{array}$ \\
\hline Pengamatan & $\begin{array}{l}\text { Pesan kesalahan Username dan } \\
\text { Password yang dimasukkan salah } \\
\text { maka tidak dapat melakukan login } \\
\text { sesuai dengan yang diharapkan }\end{array}$ \\
\hline Kesimpulan & Ditolak \\
\hline
\end{tabular}

\section{Pengujian Menu Data Master Artikel}

Table 3. Hasil Pengujian Menu Data Master Artikel

\begin{tabular}{|c|c|}
\hline \multicolumn{2}{|c|}{ Skenario 1. Hasil Pengujian (Data Normal) } \\
\hline Data Masukan & $\begin{array}{l}\text { Mengisi field data Arikel baru } \\
\text { yang telah disediakan }\end{array}$ \\
\hline Yang Diharapkan & $\begin{array}{l}\text { Proses pemasukan data selesai } \\
\text { dilakukan. Klik simpan, kemudian } \\
\text { data baru akan secara otomatis } \\
\text { masuk ke database, maka akan } \\
\text { langsung ditampilkan pada } \\
\text { datagrid master data artikel. }\end{array}$ \\
\hline Pengamatan & $\begin{array}{l}\text { Data artikel sukses dimasukan } \\
\text { setelah klik tombol simpan. Sesuai } \\
\text { dengan yang diharapkan }\end{array}$ \\
\hline Kesimpulan & Diterima \\
\hline Data Masukan & $\begin{array}{l}\text { Data Artikel yang akan dilakukan } \\
\text { penghapusan }\end{array}$ \\
\hline Yang Diharapkan & $\begin{array}{l}\text { Dapat melakukan penghapusan } \\
\text { terhadap data artikel yang akan } \\
\text { dihapus tapi pada saat mengklik } \\
\text { tombol hapus akan muncul } \\
\text { Message Box "yakin akan hapus } \\
\text { data ?" tombol ok untuk } \\
\text { meyakinkan penghapusan data } \\
\text { tombol cancel untuk tidak jadi } \\
\text { menghapus data }\end{array}$ \\
\hline
\end{tabular}

Muchamad Rusdan, Imam Yunianto, Kurniawan 


\begin{tabular}{|c|c|}
\hline Pengamatan & $\begin{array}{l}\text { Data Artikel yang telah dihapus } \\
\text { sudah tidak terdapat pada datagrid } \\
\text { data artikel. Sesuai dengan yang } \\
\text { diharapkan }\end{array}$ \\
\hline Kesimpulan & Diterima \\
\hline \multicolumn{2}{|c|}{ Skenario 2. Hasil Pengujian (Data Normal) } \\
\hline Data Masukan & $\begin{array}{l}\text { Field yang akan dilakukan } \\
\text { pengeditan }\end{array}$ \\
\hline Yang Diharapkan & $\begin{array}{l}\text { Dapat melakukan pengeditan } \\
\text { terhadap data artikel yang akan } \\
\text { diedit tapi pada saat mengklik } \\
\text { tombol edit akan muncul Message } \\
\text { Box "yakin akan edit data ?" } \\
\text { tombol ok untuk meyakinkan } \\
\text { pengeditan data tombol cancel } \\
\text { untuk tidak jadi mengedit data }\end{array}$ \\
\hline Pengamatan & $\begin{array}{l}\text { Data artikel yang telah diedit } \\
\text { dapat ditampilkan pada datagrid } \\
\text { data artikel. Sesuai dengan yang } \\
\text { diharapkan }\end{array}$ \\
\hline Kesimpulan & Diterima \\
\hline \multicolumn{2}{|c|}{ Skenario 3. Hasil Pengujian (Data Normal) } \\
\hline Data Masukan & $\begin{array}{l}\text { Masukan data artikel yang akan } \\
\text { dicari }\end{array}$ \\
\hline Yang Diharapkan & $\begin{array}{l}\text { Dapat melakukan } \\
\text { berdasarkan data yang tencarian } \\
\text { dimasukan }\end{array}$ \\
\hline Pengamatan & $\begin{array}{l}\text { Data artikel yang telah dicari } \\
\text { ditampilkan pada datagrid data } \\
\text { artikel. Sesuai dengan yang } \\
\text { diharapkan }\end{array}$ \\
\hline Kesimpulan & Diterima \\
\hline \multicolumn{2}{|c|}{ "Skenario 4. Hasil Pengujian (Data Salah) } \\
\hline Data Masukan & Nama Artikel dibiarkan kosong \\
\hline Yang Diharapkan & $\begin{array}{l}\text { Dapat menampilkan Message Box } \\
\text { kesalahan "Semua Data Harus } \\
\text { Diisi" }\end{array}$ \\
\hline Pengamatan & $\begin{array}{l}\text { Data Artikel tidak masuk ke } \\
\text { database. Sesuai dengan yang } \\
\text { diharapkan }\end{array}$ \\
\hline Kesimpulan & Diterima \\
\hline \multicolumn{2}{|c|}{ Skenario 5. Hasil Pengujian (Data Salah) } \\
\hline Data Masukan & $\begin{array}{l}\text { Data Artikel yang akan dilakukan } \\
\text { penghapusan }\end{array}$ \\
\hline Yang Diharapkan & $\begin{array}{l}\text { Jika data Artikel yang akan } \\
\text { dihapus terjadi eror dapat } \\
\text { menampilkan Message Box } \\
\text { kesalahan "Data Artikel dengan } \\
\text { ID Nama_Artikel tidak bisa } \\
\text { dihapus }\end{array}$ \\
\hline
\end{tabular}

\begin{tabular}{|c|c|}
\hline Pengamatan & $\begin{array}{l}\text { Message Box ditampilkan. Data } \\
\text { Artikel tidak bisa dihapus. Sesuai } \\
\text { dengan apa yang diharapkan }\end{array}$ \\
\hline Kesimpulan & Diterima \\
\hline \multicolumn{2}{|c|}{ Skenario 6. Hasil Pengujian (Data Salah) } \\
\hline Data Masukan & $\begin{array}{l}\text { Data Artikel yang akan dilakukan } \\
\text { pencarian }\end{array}$ \\
\hline Yang Diharapkan & $\begin{array}{l}\text { Jika data artikel yang akan dicari } \\
\text { tidak ditemukan, } \\
\text { menampilkan pesan "Data Tidak } \\
\text { Ditemukan" }\end{array}$ \\
\hline Pengamatan & $\begin{array}{l}\text { Menampilkan pesan "Data Tidak } \\
\text { Ditemukan". Sesuai dengan yang } \\
\text { diharapkan }\end{array}$ \\
\hline Kesimpulan & Diterima \\
\hline
\end{tabular}

\section{KESIMPULAN DAN SARAN}

Berdasarkan analisis, desain, dan pengujian aplikasi standar produksi dan penggunaan bahan di perusahaan kulit imitasi, sejumlah kesimpulan dapat ditarik sebagai berikut:

1. Aplikasi standar produksi dan penggunaan bahan kulit imitasi dapat mudah bagi operator, hanya perlu login. Operator dapat segera melihat standar produksi dan penggunaan bahan kulit imitasi.

2. Aplikasi standar produksi dan penggunaan bahan kulit imitasi sangat membantu dan mempercepat operator dalam menentukan standar produksi dan penggunaan bahan dengan mudah.

3. Aplikasi standar produksi dan penggunaan kulit imitasi dapat menambahkan juga mengubah isi data dalam produksi standar dan penggunaan bahan dengan mudah.

4. Aplikasi standar produksi dan penggunaan kulit imitasi sangat membantu, terutama bagi operator yang sudah berusia lanjut dalam melihat standar produksi dan penggunaan bahan yang digunakan, dan operator hanya mengetikkan kata kunci yang akan dicari, maka data akan muncul secara otomatis.

5. Aplikasi standar produksi dan penggunaan kulit imitasi dapat menjadi solusi dalam mengurangi kesalahan dalam menentukan standar produksi dan penggunaan bahan, terutama pada operator shift malam yang konsentrasinya berkurang karena kantuk.

Muchamad Rusdan, Imam Yunianto, Kurniawan 


\section{REFERENSI}

Budiartami, N. K., \& Wijaya, I. W. K. (2019). Analisis Pengendalian Proses Produksi Untuk Meningkatkan Kualitas Produk Pada CV. Cok Konveksi di Denpasar. Jurnal Manajemen Dan Bisnis Equilibrium, 5(2), 61-66.

Herawati, H., \& Mulyani, D. (2016). Pengaruh Kualitas Bahan Baku dan Proses Produksi Terhadap Kualitas Produksi Pada UD. Tahu Rosydi Puspan Maron Probolinggo. Dinamika Global: Rebranding Keunggulan Kompetitif Berbasis Kearifan Lokal, 463-482.

Limantara, C., Mulyono, G., \& Basuki, L. (2017). Perancangan Set Furnitur Sebagai Fasilitas Belajar, Bersantai, dan Penyimpanan untuk Anak Usia 3-5 Tahun Dalam Rumah Tinggal. Jurnal Intra, 5(2), 759-768. https://media.neliti.com/media/publications/954 74-ID-perancangan-set-furnitur-sebagaifasilit.pdf

Marhalim, M., Mahfuzhi, A. W., \& Fernandes, S. (2018). Pembuatan Aplikasi Pendukung Keputusan Beasiswa Tidak Mampu Dengan Metode Naive Bayes. Journal Scientific and Applied Informatics, 24-31. https://doi.org/10.36085/jsai.v1i1.6

Nagy, J., Oláh, J., Erdei, E., Máté, D., \& Popp, J. (2018). The Role and Impact of Industry 4 . 0 and the Internet of Things on the Business Strategy of the Value Chain - The Case of Hungary. Sustainability, 10(10), 1-25. https://doi.org/10.3390/su10103491

Neyfa, B. C., \& Tamara, D. (2016). Perancangan Aplikasi E-Canteen Berbasis Android Dengan Menggunakan Metode Object Oriented Analysis \& Design (OOAD). Jurnal Penelitian Komunikasi Dan Opini Publik, 20(1), 83-92. https://media.neliti.com/media/publications/123 796-ID-perancangan-aplikasi-e-canteenberbasis.pdf

Supriyanta, \& Nisa, K. (2015). Perancangan Website Desa Wisata Karangrejo Sebagai Media Informasi Dan Promosi. Jurnal Bianglala Informatika, 3(1), 35-40.

Widiastuti, A. (2006). Analisis Efisiensi Pemanfaatan Input dan Faktor-Faktor Yang Memperngaruhi Output Industri Kecil Kain Tenun Ikat "Troso."
Jurnal Dinamika Ekonomi \& Bisnis, 3(1), 85111.

Zulkifli, S., Rusli, \& Daniel. (2017). Studi kebijakan Pembangunan Pertanian Dalam Upaya Peningkatan Produksi Komoditas Unggulan Beras Adan dan Binamud di Desa Binuang Kecamatan Krayan Tengah Kabupaten Nunukan. FISIPublik: Jurnal Ilmu Sosial Dan Politik, 2(2), 1-11. https://doi.org/10.24903/fpb.v2i2.251 